\title{
The influence of chloride deicers on mineral nutrition and the health status of roadside trees in the city of Kielce, Poland
}

\author{
Agnieszka Gałuszka • Zdzisław M. Migaszewski • \\ Rafał Podlaski · Sabina Dołęgowska • \\ Artur Michalik
}

Received: 29 March 2010 / Accepted: 23 June 2010 / Published online: 10 July 2010

(C) The Author(s) 2010. This article is published with open access at Springerlink.com

\begin{abstract}
Application of chemical road deicers has a negative impact on roadside vegetation. Every year, the trees in cities suffer from direct and indirect effects of salt application for winter road maintenance. To elucidate this problem in the city of Kielce, the chemistry of snow, soil, tree bark, and leaf samples has been investigated together with an assessment of the health status of the trees. Twelve investigation sites were selected along the roads with different traffic intensity. Snow samples were collected twice during the winter and analyzed for $\mathrm{pH}, \mathrm{EC}, \mathrm{Na}^{+}, \mathrm{Ca}^{2+}$, $\mathrm{Mg}^{2+}$, and $\mathrm{Cl}^{-}$. In soil (collected from two depth intervals), tree bark, and leaf samples, the concentrations of $\mathrm{B}, \mathrm{Ca}, \mathrm{Fe}, \mathrm{K}, \mathrm{Mg}, \mathrm{Mn}, \mathrm{N}, \mathrm{Na}, \mathrm{P}, \mathrm{S}$, and $\mathrm{Zn}$ were determined. The contents of total organic carbon (TOC) in soils, as well as the $\mathrm{pH}$ of soil and tree bark samples were also measured. Nega-
\end{abstract}

A. Gałuszka $(\varangle) \cdot$ Z. M. Migaszewski ·

S. Dołęgowska · A. Michalik

Geochemistry and the Environment Div.,

Institute of Chemistry, Jan Kochanowski University, 15G Świętokrzyska Str., 25-406 Kielce, Poland

e-mail: aggie@ujk.kielce.pl

R. Podlaski

Nature Conservation Div., Institute of Biology, Jan Kochanowski University, 15 Świętokrzyska Str., 25-406 Kielce, Poland tive symptoms revealed by roadside trees included the loss of assimilative apparatus and decreased vitality. The results of chemical analyses indicated that the snowmelt might be a substantial source of chloride ions and alkalizing substances that influenced higher $\mathrm{pH}$ of soils. The soil samples displayed elevated concentrations of $\mathrm{S}$ and $\mathrm{Zn}$ and lower than typical for soil contents of $\mathrm{B}, \mathrm{Mg}$, and TOC. The $\mathrm{pH}$ of alkaline soils favored greater bioavailability of $\mathrm{B}$ and reduced bioavailability of $\mathrm{Na}$ and $\mathrm{Zn}$ by the trees examined.

Keywords Sodium chloride • Calcium chloride • Magnesium chloride $\cdot$ Roadside trees $\cdot$ Snow . Soils

\section{Introduction}

Winter road maintenance requires using chemical substances for ice and snow removal. Sodium chloride was used as a deicer in the USA as early as in 1950s (Godwin et al. 2003), and the first comprehensive environmental impact assessment of highway deicing was published by the US Environmental Protection Agency in 1971 (US EPA 1971). Of the chemical deicers, the most popular is sodium chloride $(\mathrm{NaCl})$, but calcium and magnesium chlorides $\left(\mathrm{CaCl}_{2}, \mathrm{MgCl}_{2}\right)$ are also widely used (Ramakrishna and Viraraghavan 2005). In 
the recent years, alternative road deicers have appeared commonly substituting for traditionally used chlorides in order to minimize their negative influence on the environment, building materials and metal corrosion (Robidoux and Delisle 2001; Hellstén et al. 2005). A variety of organic compounds were also tested as environmentally friendly deicers, including: calcium magnesium acetate, potassium acetate, sodium formate, calcium formate, ethylene glycol, and urea. Recently, new deicing agents, namely salts of levulinic acid produced from grain sorghum, have been proposed as an alternative to chlorides (Ganjyal et al. 2007).

Deicing substances are directly used on the road in the form of dry salts, moisturized/dissolved salts, or in a mixture with abrasive materials. They have widely been applied mostly to iced road surface, but some of the deicers have also been used to prevent ice-cover formation. Various transport mechanisms contribute to spreading of deicers to the roadside environment. By snowmelt runoff and infiltration, airborne spreading and plowing salts are distributed in the vicinity of roads (Blomqvist and Johansson 1999). The salt transport is the most intensive at a distance of about $10-20 \mathrm{~m}$ from the road (McBean and AlNassri 1987; Blomqvist and Johansson 1999). In other studies, on the influence of chemical deicers on urban soils and groundwaters, a downward migration of salts through the soil profile to bedrock has also been confirmed (e.g., Thunqvist 2004; Cunningham et al. 2008).

A long-term use of sodium chloride for winter road maintenance leads to accumulation of sodium and chloride especially in the urban environment (Godwin et al. 2003; Ramakrishna and Viraraghavan 2005; Green et al. 2008; Cunningham et al. 2008). It should be stressed that all the chemical deicers, regardless of their composition, influence the chemistry of waters, soils, and vegetation. The problem of groundwater and surface water contamination with chloride ions as an effect of road deicer application has been observed in many regions (Rosenberry et al. 1999; Thunqvist 2004; Novotny et al. 2008; Kincaid and Findlay 2009). Some of the authors claim (e.g., Howard and Maier 2007) that the raised concentrations of chlorides in groundwaters which are a source of drinking water for the growing population of urbanized areas may be a serious problem for the future development of conurbations. The snowmelt runoff and influx of chloride-rich groundwaters to surface waters adversely influence biota, change stratification, and density gradients in lakes, leading to disturbance of water circulation (Judd 1970; Thunqvist 2004).

In addition, a long-lasting use of chemical deicers has a detrimental impact on soils. Chlorides used for melting ice and snow change the soil properties. The cation exchange sites in soils absorb $\mathrm{Na}^{+}, \mathrm{Mg}^{2+}$, and $\mathrm{Ca}^{2+}$, whereas the chloride ions are transported through the soil to ground and surface waters (Ramakrishna and Viraraghavan 2005). If these absorbed cations substitute for important plant nutrients, such as $\mathrm{Zn}, \mathrm{Cu}, \mathrm{K}$, and $\mathrm{Mn}$, this exchange can have a potentially detrimental effect to plant physiology. High concentrations of sodium in soil cause dispersion of soil colloids, leading to reduction in soil permeability and increased erosion rate (Cunningham et al. 2008). Accumulation of deicing salts in urban soils may lead to changes in ecological structure of soil organism communities (Green et al. 2008) with an increasing population density of salt-tolerant (halophilic) species.

Many authors have emphasized the negative effect of road deicers on roadside vegetation (e.g., Viskari and Kärenlampi 2000; Kayama et al. 2003; Trahan and Peterson 2007). Plants subjected to pollution caused by road deicers show negative symptoms at biochemical, physiological, and community levels. High concentrations of chlorides and sodium inhibit cell membrane functions, causes osmotic stress, and cell plasmolysis and decrease chlorophyll level leading to disorders in photosynthesis. Most of the studies on the influence of chemical deicers on plants concern the most popular salt-sodium chloride. The influence of $\mathrm{NaCl}$ on plants can be both direct (a high uptake and accumulation of sodium and chloride ions) and indirect (an influence of this salt on soil properties and plant nutrient bioavailability). The most often recorded response to high $\mathrm{NaCl}$ content in soils is leaf chlorosis and in more severe cases also necrosis. Laboratory studies on the influence of sodium chloride on different tree species seedlings revealed that the intensity of leaf necrosis depended on the salt tolerance of a given 
tree species to the water regime and soil type (Fostad and Pedersen 2000). The salt tolerance of tree species may be an important factor for urban greenery designing (Sæbø et al. 2003). The currently published data displayed that magnesium chloride regarded as a more environmental friendly deicer (applied in amounts comparable to $\mathrm{NaCl}$-based sand and salt mixtures) was more damaging to two pine species Pinus ponderosa and Pinus contorta (Trahan and Peterson 2008). Some information is also available on the negative impact of $\mathrm{MgCl}_{2}$, used as a dust suppressant, on vegetation (e.g., Goodrich et al. 2008, 2009).

A negative influence of chemical deicers on the environment is also caused by substances used in technological processes of improving the quality of these products. These chemicals (named anticaking agents) encompass complex cyanide compounds (sodium ferrocyanide, ferric ferrocyanide), chromates, and phosphates (Ramakrishna and Viraraghavan 2005). Ferrocyanide compounds degrade in the environment to free cyanide ions bringing about a toxicological risk to living organisms. This degradation occurs when salt dissociates in water at $\mathrm{pH}<8$ and $\mathrm{Eh}$ greater than $-600 \mathrm{mV}$. Fortunately, natural waters scarcely show both high alkalinity and low redox potential values (Novotny et al. 1998).

The recent studies on the environmental impact of chemical road deicers have stressed a complex influence of these substances on the environment. This complexity is highlighted by indirect (or secondary) effects of pollution on geochemical processes, especially on increasing mobility of heavy metals in soils (Bäckström et al. 2004; Norrström and Jacks 1998; Norrström 2005; Rasa et al. 2006), selective retention of $\mathrm{Na}, \mathrm{Ca}$, and $\mathrm{Mg}$ combined with high mobility of chloride ions in soils (Cunningham et al. 2008), or disturbance of nitrogen transformations in soils (Green et al. 2008). Although the results of comprehensive studies on the influence of road deicers on the environment have been published (e.g., Cekstere et al. 2008; Czerniewska-Kusza et al. 2004), still little is known on the geochemical behavior of salt constituents in snow-soil-plant systems. To give a better insight into this problem, we carried out a study on mineral nutrition and the health status of roadside trees in the city of Kielce (south-central
Poland). The principal objectives of this study were: (1) to compare the chemistry of snow and soils with concentrations of selected elements in leaves and bark of trees growing close to the roads and (2) to assess the health status of these trees and find the possible cause of negative symptoms.

\section{Materials and methods}

Location of investigation sites

The study was carried out in Kielce (south-central Poland). The city covers up an area of $109.45 \mathrm{~km}^{2}$ and its geographic coordinates are $20^{\circ} 38^{\prime}$ East longitude and $50^{\circ} 53^{\prime}$ North latitude. The city of Kielce is located within the western part of the Kielce--Łagów Valley and is a capital of the Swiętokrzyskie Province. The city is surrounded by hills and mountain ranges. The difference in elevation within the city limits ranges from 260 to $406 \mathrm{~m}$ above sea level. Kielce plays an important role in a road transport network of Poland. There are three national roads in the city. The mean traffic intensity in the city center is above 1,000 vehicles per hour.

Six streets were selected as investigation sites. Each of these sites encompassed two sampling points localized on opposite sides of the street (Fig. 1). The sites represented three different winter road maintenance strategies. At four sites (1a, 1b, 2a, 2b) $\mathrm{NaCl}$ was applied, whereas at eight sites $\mathrm{NaCl}$ and other chlorides were alternatively used: $\mathrm{CaCl}_{2}$ (3a, 3b, 4a, 4b) and $\mathrm{MgCl}_{2}$ (5a, 5b, 6a, 6b).

Of the investigation sites, the highest traffic intensity ( $>2,000$ cars per hour) occurs at sites $2 \mathrm{a}$, $2 \mathrm{~b}, 4 \mathrm{a}, 4 \mathrm{~b}$, moderate traffic intensity $(1,000-2,000$ cars per hour) is recorded at sites $1 \mathrm{a}, 1 \mathrm{~b}, 3 \mathrm{a}, 3 \mathrm{~b}$, and the lowest traffic intensity $(<1,000$ cars per hour) is noted at sites 5a, 5b, 6a, 6b (unpublished data derived from the Municipality of Kielce).

\section{Sampling}

Sampling was done in two phases. Snow samples were collected in the winter (February 1 and 26, 2009), whereas soil and plant samples in the late spring (June 9) of 2009. The reason for collecting 


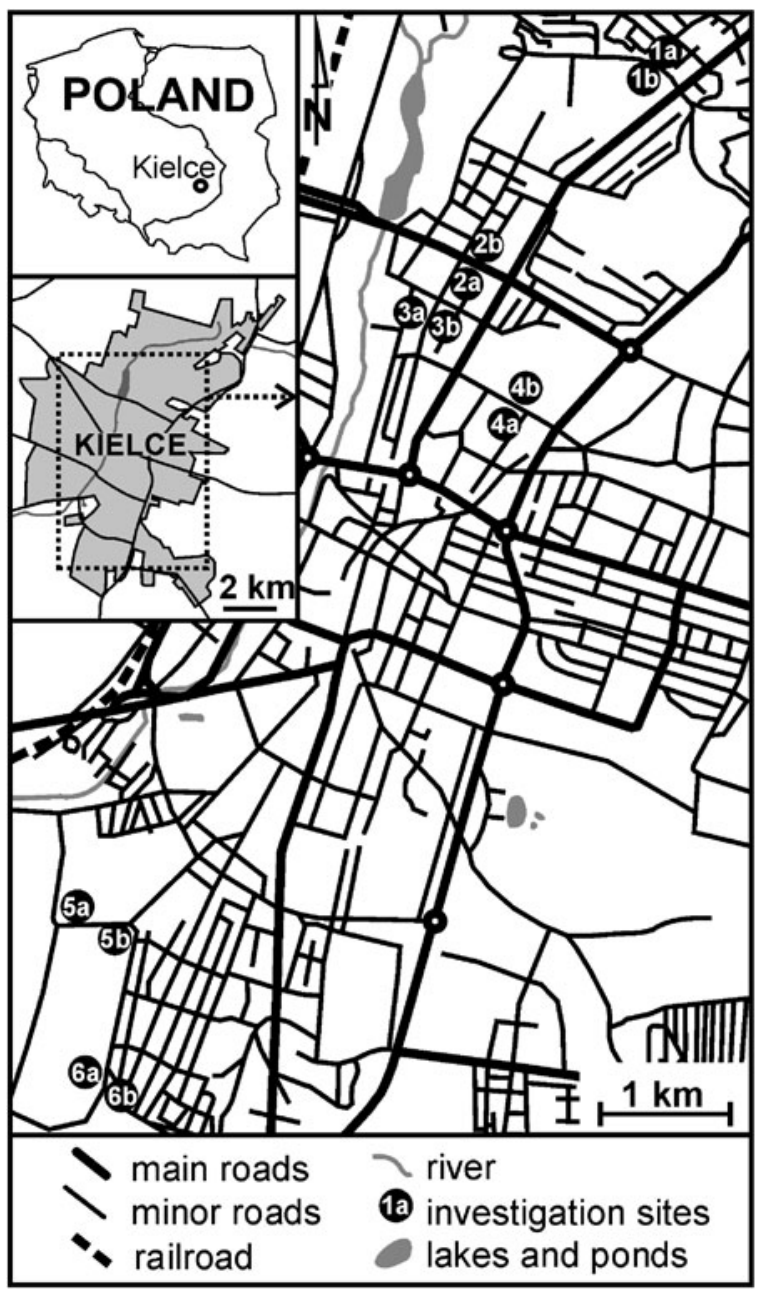

Fig. 1 Study area and localization of investigation sites

snow samples in a short period of time in the late winter was the possibility to compare snow chemistry in similar climatic conditions before spring snowmelt. Trees were sampled in June when the leaves were fully developed. Snow samples were placed in plastic containers. At each investigation site two soil samples were collected in plastic bags from the depth intervals of $0-0.15 \mathrm{~m}$ and 0.4 $0.6 \mathrm{~m}$. Bark and leaves of four tree species growing at a distance of 0.3 to $2 \mathrm{~m}$ from the road edge were collected in paper bags at 12 investigation sites and 4 control sites: ash Fraxinus excelsior L. (7 sites), linden Tilia cordata Mill. and Tilia platyphyllos Scop. (3), pine Pinus sylvestris L.
(4) and maple Acer pseudoplatanus L. (2). Each composite plant sample consisted of about 10 subsamples. All these samples were transported to the Laboratory of Geochemistry and the Environment Division of Jan Kochanowski University in Kielce. During sampling stainless steel tools were used and precautions were made to prevent the samples from contamination.

Sample preparation and analyses

The snow samples were melted at ambient temperature (about $20^{\circ} \mathrm{C}$ ) and filtered. Subsequently, the $\mathrm{pH}$, and conductivity (EC) were measured with a CP-103 pH-meter and a CC-101 ECmeter (Elmetron, Poland). The concentrations of sodium in the snow samples were determined with a sodium ion selective electrode using a CX-742 multifunctional measuring apparatus (Elmetron, Poland). The chloride ion concentrations were determined with a LF205 spectrophotometer (Slandi, Poland). Calcium and magnesium ion concentrations were analyzed using complexometric titration method.

The soil samples were air-dried and disaggregated with a Fritsch's blender to pass a $0.063 \mathrm{~mm}$ sieve. One gram of each soil sample was digested with $50 \mathrm{ml}$ of aqua regia in a closed microwave system (MDS 81, CEM Corp.). The air-dried plant samples were pulverized with an IKA Werke plant material blender and sieved to $0.5 \mathrm{~mm}$ fraction. The plant samples were digested in a closed microwave system with $\mathrm{HNO}_{3}$ and $\mathrm{H}_{2} \mathrm{O}_{2}(0.5 \mathrm{~g}$ of sample $+5 \mathrm{ml} \mathrm{HNO}_{3}+1 \mathrm{ml} \mathrm{H}_{2} \mathrm{O}_{2}$ ) (US EPA 1996). In addition, for the purpose of the $\mathrm{pH}$ measurements, the disaggregated soil and bark samples were placed in beakers and mixed with deionized water in the proportion: $10 \mathrm{~g}+25 \mathrm{ml}$ (soil) and $1.5 \mathrm{~g}+20 \mathrm{ml}$ (bark). After $24 \mathrm{~h}$, the $\mathrm{pH}$ of filtered solutions was measured using a CP-103 $\mathrm{pH}$ meter.

The soil and plant samples were analyzed for B, $\mathrm{Ca}, \mathrm{Fe}, \mathrm{K}, \mathrm{Mg}, \mathrm{Mn}, \mathrm{Na}, \mathrm{P}, \mathrm{S}$, and $\mathrm{Zn}$ using inductively coupled plasma optical emission spectrometry (ICP-OES; spectrometer Jobin-Yvon model JY 70 PLUS with vertical plasma). For analytical quality assurance, $10 \%$ of all samples were randomly selected for routine replicate analyses, and 
reference standard materials, i.e., Lake Sediment LKSD-3 (for soils) and Citrus leaves SRM-1572 (for plants), were used. The total organic carbon (TOC) content of soil samples was determined with an automatic Coulometric titration method (Coulomat 702 C/S, Stróhlein, Germany).

The concentrations of total nitrogen were determined using an automated spectrophotometric flow injection analyzer (FIAstar, FOSS) (Lima et al. 2000). Digestion of samples was done in a digestion block (FOSS Tecator DS 12) with $\mathrm{H}_{2} \mathrm{SO}_{4}$.

The element determinations were performed in the Central Chemical Laboratory of the Polish Geological Institute in Warsaw, whereas the remaining analyses in the Laboratory of Geochemistry and the Environment Division of Jan Kochanowski University in Kielce

Tree health status assessment

The tree health status assessment was done on the day of soil and plant sampling (June 9, 2009). Measurements and observations (tree diameter at $1.3 \mathrm{~m}$ above ground level (DBH), degree of defoliation, tree top shape, and vitality) were considered when analyzing the health status of the trees examined. As health status cannot be measured directly, various indicators can instead serve to describe tree vitality (Dobbertin 2005). Field practical methods are of great importance in tree health status assessment. The most importance field methods include crown foliage (degree of defoliation) and crown morphology (tree top shape).

The selected trees were classified according to the following characteristics (Borecki and Keczyński 1992): (1) degree of defoliation (four classes: 0-no defoliation; loss of assimilative apparatus up to $10 \%, 1-$ slight defoliation; loss of assimilative apparatus from $11 \%$ to $25 \%$, 2 -moderate defoliation; loss of assimilative apparatus from $26 \%$ to $60 \%, 3$-severe defoliation; loss of assimilative apparatus more than $60 \%$ ), (2) tree top shape (four classes: 1 -conical top, 2-narrowly paraboloidal top, 3-broadly paraboloidal top, 4-flat top); (3) vitality (five classes: 1-trees luxuriantly developed, 2-trees normally developed, 3-trees slightly weakened,
4 - trees strongly weakened, 5-dying trees). The degree of tree damage was assessed on the basis of percentage degree of defoliation, according to the European forest monitoring methodology (Lorenz 1995). In determination of vitality all characteristics giving a full picture of the tree were taken into account: degree of defoliation, tree top shape, and some other characteristics as for example length of the crown and degree of crown deformation (Innes 1993). For comparison, the distribution patterns of degree of defoliation, tree top shape, and vitality between sites investigated, the Kruskal-Wallis test was applied. For any characteristic for which a difference was observed with the Kruskal-Wallis test, the significance of differences between groups was examined by the Bonferroni test.

\section{Results}

Snow

The results of $\mathrm{pH}, \mathrm{EC}$, and ion determinations in the snow samples collected in two series are presented in Table 1 . The $\mathrm{pH}$ of snow from the first sampling series was in the range of 6.68.1 with a mean of 7.3 , and from the second series in the range 6.0-7.1 (mean of 6.8). The distinct differences in electrical conductivity were noted between the two sampling series. The much higher EC values $(242-5,080 \mu \mathrm{S} / \mathrm{cm}$; mean of $1,320 \mu \mathrm{S} / \mathrm{cm}$ ) were recorded in the snow collected during the first sampling series. The EC of snow from the second series were lower varying from 160 to $492 \mu \mathrm{S} / \mathrm{cm}$ (mean of $286 \mu \mathrm{S} / \mathrm{cm}$ ). The high EC values reflected the distinctly higher ion concentrations. The mean concentrations of chloride ions were four times higher, calcium and magnesium ions almost twice, and sodium ions seven times higher in the snow from the first sampling series.

\section{Soil}

The chemical composition and $\mathrm{pH}$ of soil samples are displayed in Table 2. In contrast to the deeper sampling interval $(0.4-0.6 \mathrm{~m})$, the surface soil (0$0.15 \mathrm{~m}$ ) was enriched in most of the elements, 


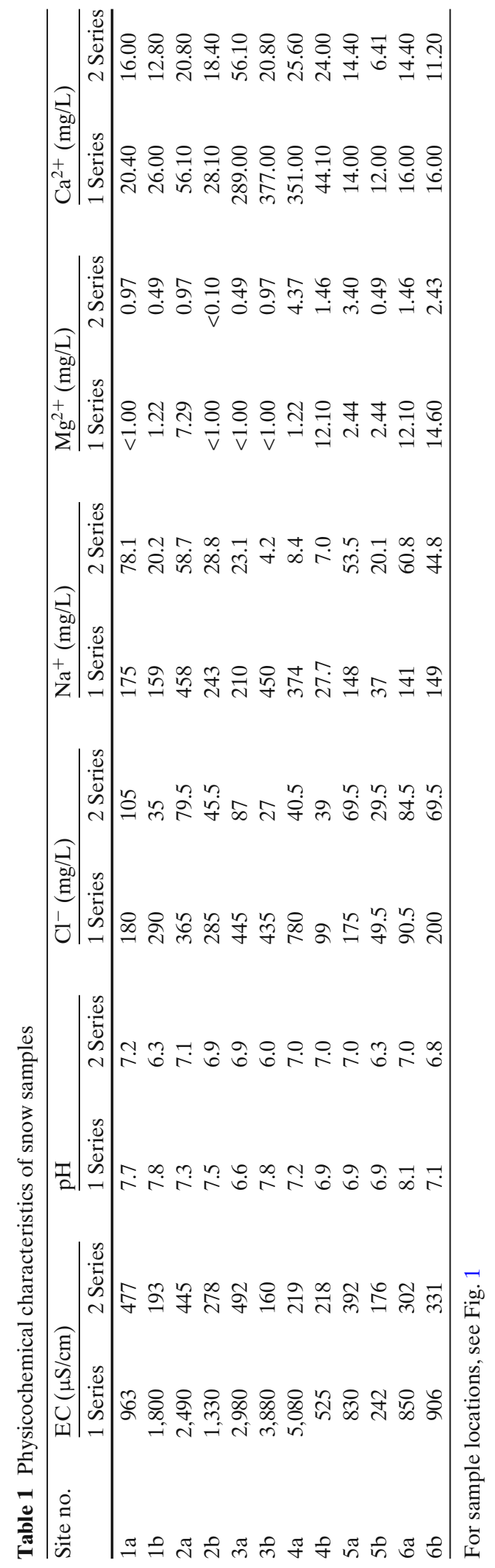




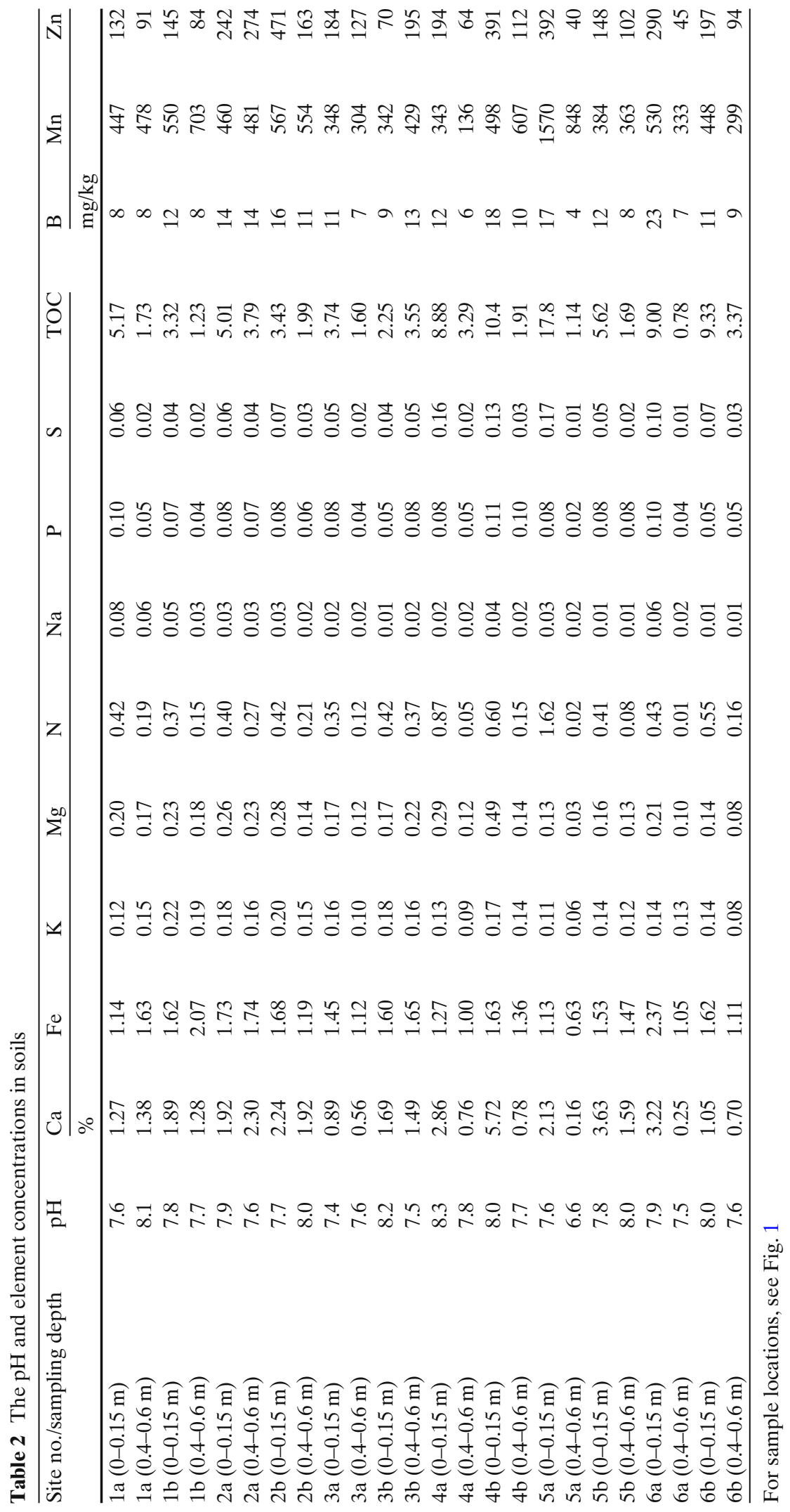




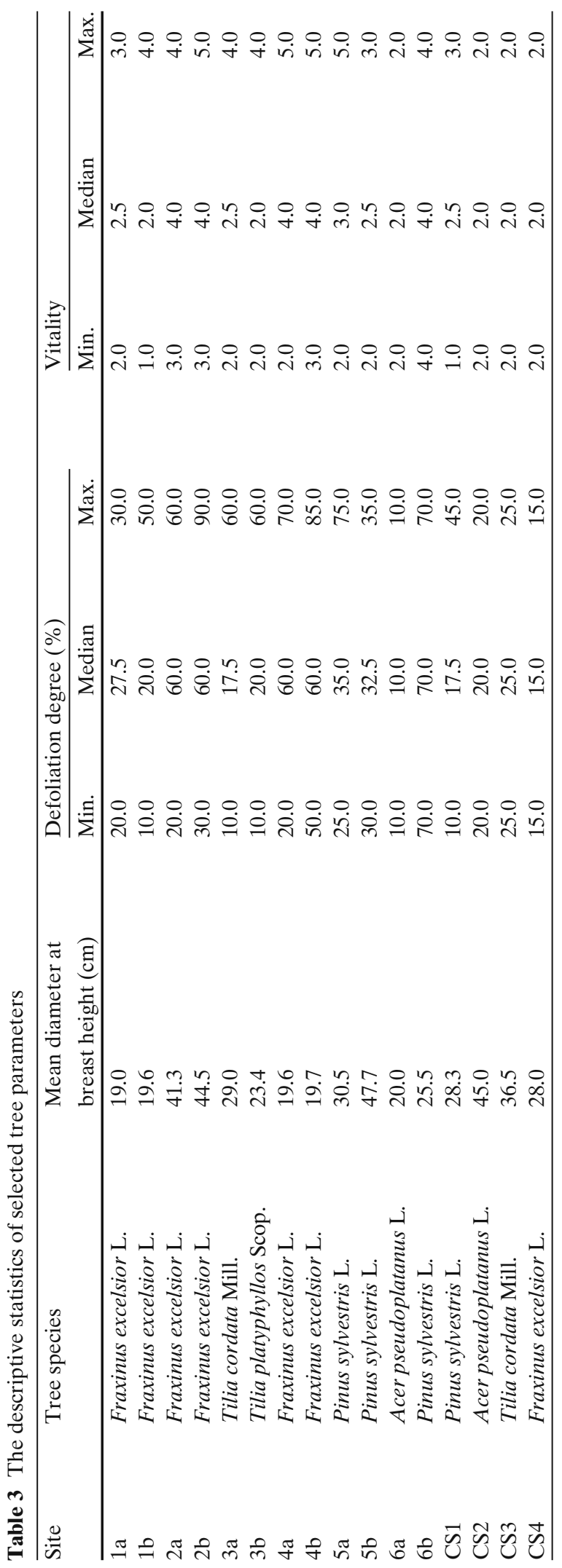




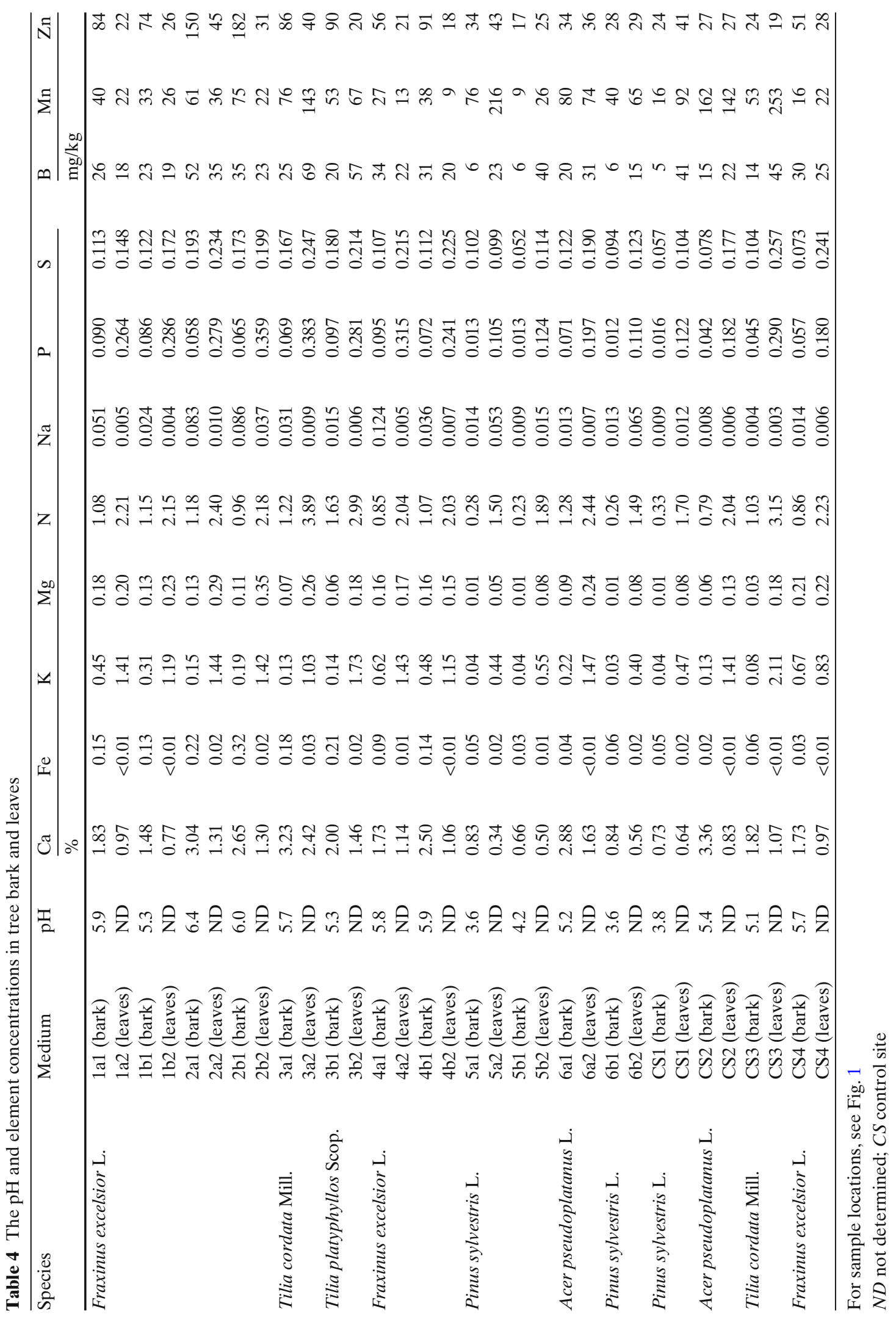


except for potassium which was distributed evenly in the soil profile. The total organic carbon and $\mathrm{pH}$ also showed increased values in the upper part of the soil profile.

\section{Plant material}

The descriptive statistics of selected tree features is given in Table 3 and the chemical composition of bark and leave samples is presented in Table 4. There are interspecies differences in accumulation of elements in the bark and leaves. The $\mathrm{pH}$ of ash bark was similar to that of linden and maple bark (about 5.5-6.00), whereas the pine bark was more acidic (3.6-4.2). Some of the elements were accumulated in the bark ( $\mathrm{Ca}, \mathrm{Fe}, \mathrm{Mn}, \mathrm{Na}, \mathrm{Zn})$ and the others in the leaves $(\mathrm{B}, \mathrm{K}, \mathrm{Mg}, \mathrm{N}, \mathrm{P}, \mathrm{S})$.

The health status assessment showed that there were negative symptoms within the trees examined. Statistically significant differences were found in the following parameters: (1) the loss of assimilative apparatus between sites $2 \mathrm{a}, 2 \mathrm{~b}$ and 1a, $1 \mathrm{~b}$, control site no. 3 ; sites $4 \mathrm{a}, 4 \mathrm{~b}$ and $1 \mathrm{a}$, $1 \mathrm{~b}$, control site no. 3 (Kruskal-Wallis test, $p<$ $0.0001)$; (2) the tree-top shape between sites $2 \mathrm{a}$, $2 \mathrm{~b}$ and control site no. 3 (Kruskal-Wallis test, $p=$ 0.0023 ); (3) vitality between sites $2 \mathrm{a}, 2 \mathrm{~b}$ and $1 \mathrm{a}, 1 \mathrm{~b}$, control site no. 3; sites 4a, 4b and 1a, 1b, control site no. 3 (Kruskal-Wallis test, $p<0.0001$ ).

\section{Discussion}

Chemistry of snow, soil, and tree bark and leaves

Snowpack is the most important pollution source when interpreting the influence of chemical deicers on the environment. Most of the analyzed snow samples exhibited the raised concentrations of ions originating from the chlorides used. This is particularly evidenced by the concentrations of calcium ion at sites 3 and 4. Major variations in the chemistry were noted between snow samples collected on February 1 and 26. This may be explained by the differences in weather conditions (e.g., wind strength and direction, temperature) during sampling, as well as by the duration of snowpack. During the first sampling series, the snow cover was fresh (samples were collected on the consecutive day after the snowfall) averaging about $2 \mathrm{~cm}$ in thickness. In contrast, during the second sampling series, the snowpack was about $30 \mathrm{~cm}$ thick following heavy snowfall.

There are strong, statistically significant positive correlations $(p<0.05)$ between EC and chloride concentrations in the snow examined $\left(R^{2}=\right.$ 0.93 in the first series and $R^{2}=0.82$ in the second series). Distinctly higher correlation coefficients are also noted between EC and $\mathrm{Ca}^{2+}\left(R^{2}=0.82\right)$ as well as EC and $\mathrm{Na}^{+}\left(R^{2}=0.65\right)$ in the first snow sampling series. This evidence suggests that the chloride ion concentrations are the major factor that influences the EC values in the snow samples.

The $\mathrm{pH}$ of soil samples was slightly alkaline varying from 6.6 to 8.3 with a mean of 7.7 . The similar $\mathrm{pH}$ values (6.66-8.11) were found in soils by Green and co-authors at Selside (UK), where roads were maintained with sodium chloride (Green et al. 2008). Roadside soils collected near Stockholm (Sweden) revealed a $\mathrm{pH}$ close to neutral in the 6.6-7.0 range (Norrström and Jacks 1998). It should be emphasized that soils of the Kielce area are developed on Upper Devonian marlaceous clayey shales, marls, and limestones, and that is why their natural $\mathrm{pH}$ exceeds 6.5. Salts used as deicers may cause an increase of $\mathrm{pH}$ values in soils, which is evidenced by a higher $\mathrm{pH}$ in the surface layer of eight sampling points.

The use of calcium chloride as a deicer at sites $3 \mathrm{a}, 3 \mathrm{~b}, 4 \mathrm{a}$, and $4 \mathrm{~b}$ might have been contributed to calcium accumulation in soils. Compared to sodium, calcium is easier retained in soils. The long term application of calcium chloride may trigger the geochemical interactions of $\mathrm{Ca}$ with other elements in soils and affect their bioavailability for plants.

Concentrations of some elements in the soils examined do not substantially differ from those reported as typical levels in soils, for example, Fe and partly Mn (Kabata-Pendias and Pendias 2001), or found in natural forest ecosystems of the Holy Cross Mountains, for example, $\mathrm{K}$ and $\mathrm{P}$ (Gałuszka 2005).

The mean concentration of $\mathrm{Na}$ in soils from unpolluted sites is $0.63 \%$ (Tan 2005) and in the soils examined the content of this element varied from $0.01 \%$ to $0.08 \%$. Nearly the same 
concentrations of $\mathrm{Na}(0.013-0.057 \%)$ were found by Cunningham and co-authors (2008) in roadside soils of New York State. According to Kayama and co-authors (2003), roadside soils in Northern Japan contained similar concentrations of sodium $(0.009-0.047 \%)$. The same levels of this element $(0.003-0.033 \%)$ were also found in roadside soils in Opole (Czerniewska-Kusza et al. 2004).

The roadside soils of the Kielce area showed lowered contents of magnesium (0.03-0.49\%) and TOC $(0.78-17.80 \%)$. Similarly, low concentrations of this element were also recorded in roadside soils by other authors, for example, $0.03 \%$ (Cunningham et al. 2008), 0.007-0.035\% (Kayama et al. 2003), <0.001\% (Czerniewska-Kusza et al. 2004). Although low concentrations of TOC are typical for urban soils, the decreased contents of organic compounds in the soils studied are a concern. The presence of increased amounts of organic carbon facilitates proper soil structure and cation exchange and, moreover, is a source of nutrients for soil microorganisms. There is a positive correlation between TOC and N concentrations $\left(R^{2}=0.84\right)$, as well as between TOC and $\mathrm{S}$ concentrations $\left(R^{2}=0.83\right)$ in the soils examined, which provides evidence for the occurrence of $\mathrm{S}$ and $\mathrm{N}$ in organic form.

The concentrations of sulfur $(0.01-0.17 \%)$ and zinc $(40-471 \mathrm{mg} / \mathrm{kg})$ in the soils of the Kielce area exceeded those $(0.05 \% \mathrm{~S}$ and $50 \mathrm{mg} / \mathrm{kg} \mathrm{Zn})$ recorded in soils by Foth and Ellis (1996). In a majority of investigation sites these elements were accumulated in the surface soil layer $(0-0.15 \mathrm{~m})$.

The results of plant material analysis showed that some elements are accumulated in the tree bark $(\mathrm{Ca}, \mathrm{Fe})$ and others in the leaves $(\mathrm{K}, \mathrm{Mg}$, $\mathrm{N}, \mathrm{P}, \mathrm{S}, \mathrm{Zn}$ ). Low concentrations of iron in these leaves were similar to those found in edible plants (Kabata-Pendias and Pendias 2001). The concentrations of potassium in the tree bark did not differ from those recorded previously in the Holy Cross Mountains (Gałuszka 2005), but the levels of $\mathrm{K}$ in the leaves were higher than those reported from the Holy Cross Mountains (Migaszewski et al. 2004). No substantial differences between $K$ concentrations in the samples from investigation and control sites were found.

The concentrations of magnesium showed interspecies differences. The lowest $\mathrm{Mg}$ concentra- tions were found in the bark of linden (0.03$0.07 \%)$. For comparison, the typical contents of $\mathrm{Mg}$ in plants are in the $0.1-0.3 \%$ range (KabataPendias and Pendias 2001). The bark exhibited a positive correlation between the $\mathrm{Mg}$ content and $\mathrm{pH}\left(R^{2}=0.72\right)$.

Of the elements determined in plant material samples, only the concentrations of sulfur and sodium were higher than those characteristic for plants. Sodium accumulated in most of the bark samples. The concentrations of sulfur in the tree bark $(0.052-0.193 \%)$ and leaves (0.099$0.257 \%$ ) were twice as high as typical contents of this element in trees growing in forest ecosystems of the Holy Cross Mountains (0.023-0.110\%) (Migaszewski et al. 2004). Sulfur is an important constituent of polipeptydes responsible for detoxication of phytotoxic metals in plants. Accumulation of sulfur in roadside trees may thus be linked to the enrichment of urban soils in metals. However, this hypothesis needs further studies. The maximum concentrations of sodium in the bark and leaves were $0.124 \%$ and $0.065 \%$, respectively. These concentrations differ from those reported for tree leaves by Czerniewska-Kusza et al. (2004) $(0.18-1.01 \%)$ or by Cekstere et al. (2008) who recorded maximum values of $1.93-2.1 \%$. However, it should be stressed that $\mathrm{Na}$ concentrations in trees change seasonally (Cekstere et al. 2008) and the time of sampling may play an important role when comparing the results derived from different studies.

\section{Elements transfer from soil to plants}

Soil $\mathrm{pH}$ is a very important factor that influences bioavailability of elements for plants. The mean $\mathrm{pH}$ of the soil examined was 7.7, whereas the observed range was 6.6-8.3. The optimal soil $\mathrm{pH}$ value for plant nutrition is 6.5 and if it exceeds 7.5 , the uptake of important elements, such as $\mathrm{Zn}, \mathrm{P}$, $\mathrm{Mn}, \mathrm{Cu}$, and $\mathrm{Fe}$, is hampered (Adams and Early 2004).

The use of chloride deicers at the sampling sites resulted in increased soil alkalinity, which, in turn, influenced higher bioavailability of boron for plants. The contents of this trace element in the soils were low $(4-23 \mathrm{mg} / \mathrm{kg})$. In contrast, the 
tree samples showed concentrations of B about three times as high as those in soils. In twelve samples of plant material concentrations of $\mathrm{B}$ were higher than the optimal level $(30 \mathrm{mg} / \mathrm{kg})$ for plants (Kabata-Pendias and Pendias 2001). There was a statistically significant positive correlation between the $\mathrm{B}$ concentrations and $\mathrm{pH}$ in the upper soil and tree bark $\left(R^{2}=0.81\right)$.

The upper soil $\mathrm{pH}$ and concentrations of $\mathrm{Ca}$, $\mathrm{Mg}, \mathrm{N}$ and $\mathrm{P}$ in the tree bark displayed positive correlations between the following pairs: $\mathrm{pH}-\mathrm{Ca}$ $\left(R^{2}=0.58\right), \mathrm{pH}-\mathrm{Mg}\left(R^{2}=0.63\right), \mathrm{pH}-\mathrm{N}\left(R^{2}=\right.$ $0.59)$, $\mathrm{pH}-\mathrm{P}\left(R^{2}=0.62\right)$. These relationships may be an indication of the influence of soil $\mathrm{pH}$ on translocation of elements within the tree organs.

A need for determining $\mathrm{K} / \mathrm{Na}$ ratio in urban soils and plants has been recently mentioned (Cekstere et al. 2008). The $\mathrm{K} / \mathrm{Na}$ and $\mathrm{Ca} / \mathrm{Na}$ ratios are indicative for soil salinity (Porcelli et al. 1995). In the present study, these ratios were the highest at control sites (Fig. 2), which were not influenced directly by chloride road deicers. It is interesting to note that at investigation sites, in which the trees have shown the most intensive negative symptoms, the leaves displayed the lowest $\mathrm{K} / \mathrm{Na}$ and $\mathrm{Ca} / \mathrm{Na}$ ratios.

It is a known fact that roadside trees are especially prone to decline. There are many reasons for this vulnerability. Chloride deicers applied on the roads every year cause negative symptoms such as chlorosis and the loss of assim- ilative apparatus. Other pollutants, for example, engine exhaust components are often phytotoxic. Besides, various building foundations, sidewalks, or roads restrict root growth and contribute to tree damages. The combination of different stress factors influencing roadside trees often leads to tree death.

The loss of assimilative apparatus and decreased vitality were the most intensive at sites $2 \mathrm{a}, 2 \mathrm{~b}, 4 \mathrm{a}$, and $4 \mathrm{~b}$. The trees growing at sites $1 \mathrm{a}$, $1 b, 3 a$, and $3 b$ were the healthiest. A type of salt used for winter road maintenance does not seem to contribute to intensity of negative symptoms in the tree examined. In the winter season of 2008/2009 the roads at sites 1a, 1b, 2a, 2b were treated with sodium chloride, while the roads at sites $3 \mathrm{a}, 3 \mathrm{~b}, 4 \mathrm{a}$, and $4 \mathrm{~b}$ with calcium chloride.

The most probable cause of negative symptoms is the road traffic intensity (the highest at sites $2 \mathrm{a}$, $2 \mathrm{~b}$ and $4 \mathrm{a}, 4 \mathrm{~b})$. Another factor is the distance of the tree from the road (the lowest was $<0.5 \mathrm{~m}$ at site $4 a$ ). The recent study by Zehetner et al. (2009) indicated that the road salt residues (as well as PAHs and total and mobile heavy metals) decreased exponentially with distance from the road. Different studies on the influence of chemical deicers on roadside vegetation also provided evidence for the highest risk of toxicity as a result of direct deposition of salt on plant organs (Trahan and Peterson 2007; Viskari and Kärenlampi 2000).
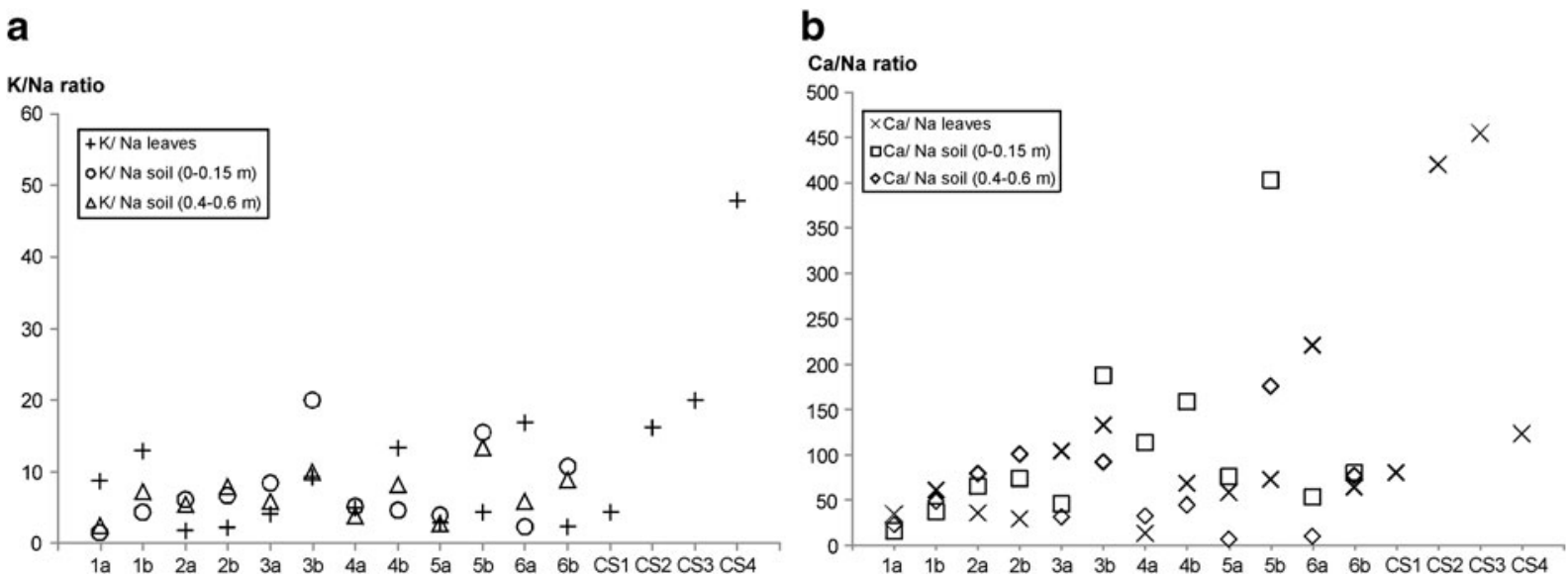

Fig. $2 \mathrm{~K} / \mathrm{Na}$ and $\mathrm{Ca} / \mathrm{Na}$ ratios in tree leaves and soils 


\section{Conclusions}

Chemical analyses of snow collected in the vicinity of roads maintained with three different chloride deicers showed that the snowmelt might be an important source of alkalizing substances and chloride ions in soils. This process may bring about an increase of soil $\mathrm{pH}$ which may decrease bioavailability of important plant nutrients. The concentrations of $\mathrm{S}$ and $\mathrm{Zn}$ in the studied soils were higher and the concentrations of $\mathrm{B}, \mathrm{Mg}$, $\mathrm{Na}$, and TOC were lower compared to the chemistry of typical soils. The alkaline soil $\mathrm{pH}$ brought about increased bioavailability of B and decreased bioavailability of $\mathrm{Na}$ and $\mathrm{Zn}$. Negative symptoms revealed by the roadside trees, i.e., the loss of assimilative apparatus and decreased vitality, were most frequently observed at the sites with the highest traffic intensity and at the sites where trees grew closest to the road. The roadside trees decline is most probably caused by dissolved contaminants released to soil during snowmelt, but it also may be increased by a possible synergistic effect with winter temperature extremes.

The center of a city provides very difficult conditions for plant growth, and the seasonal systematic use of chemical deicers is just one of the possible causes of chemical stress for urban greenery. The influence of road deicers on the city environment is more complex than the direct influx of chemical substances to soils or waters. This influence affects biogeochemical processes in water-soil-plant systems with a serious consequence for plant nutrition.

Acknowledgements This study was financed by the Kielce Municipality. The staff of the Central Chemical Laboratory of the Polish Geological Institute are gratefully acknowledged for their analytical assistance.

Open Access This article is distributed under the terms of the Creative Commons Attribution Noncommercial License which permits any noncommercial use, distribution, and reproduction in any medium, provided the original author(s) and source are credited.

\section{References}

Adams, C. R., \& Early, M. P. (2004). Principles of horticulture. Oxford: Elsevier.
Bäckström, M., Karlsson, S., Bäckman, L., Folkeson, L., \& Lind, B. (2004). Mobilization of heavy metals by deicing salts in a roadside environment. Water Research, 38, 720-732. doi:10.1016/j.watres.2003.11.006.

Blomqvist, G., \& Johansson, E. -L. (1999). Airborne spreading and deposition of de-icing salt - a case study. The Science of the Total Environment, 235, 161168. doi:10.1016/S0048-9697(99)00209-0.

Borecki, T., \& Keczyński, A. (1992). Atlas of the loss of assimilative apparatus (in Polish). Warsaw: Agencja ATUT.

Cekstere, G., Nikodemus, O., \& Osvalde, A. (2008). Toxic impact of the de-icing material to street greenery in Riga, Latvia. Urban Forestry \& Urban Greening, 7, 207-217. doi:10.1016/j.ufug.2008.02.004.

Cunningham, M. A., Snyder, E., Yonkin, D., Ross, M., \& Elsen, T. (2008). Accumulation of deicing salts in soils in an urban environment. Urban Ecosystem, 11, 17-31. doi:10.1007/s11252-007-0031-x.

Czerniewska-Kusza, I., Kusza, G., \& Dużyński, M. (2004). Effect of deicing salts on urban soils and health status of roadside trees in the Opole region. Environmental Toxicology, 19(4), 296-301. doi:10.1002/tox.20037.

Dobbertin, M. (2005). Tree growth as indicator of tree vitality and of tree reaction to environmental stress: A review. European Journal of Forest Research, 124, 319-333. doi:10.1007/s10342-005-0085-3.

Fostad, O., \& Pedersen, P. A. (2000). Container-grown tree seedling responses to sodium chloride applications in different substrates. Environmental Pollution, 109, 203-210. doi:10.1016/S0269-7491(99)00266-3.

Foth, H. D., \& Ellis, B. G. (1996). Soil fertility, 2nd Edn. New York: Lewis.

Gałuszka, A. (2005). The chemistry of soils, rocks and plant bioindicators in three ecosystems of the Holy Cross Mountains, Poland. Environmental Monitoring and Assessment, 110, 55-70. doi:10.1007/s10661005-6290-1.

Ganjyal, G., Fang, Q., \& Hanna, M. A. (2007). Freezing points and small-scale deicing tests for salts of levulinic acid made from grain sorghum. Bioresource Technology, 98, 2814-2818. doi:10.1016/j.biortech.2006. 07.042.

Godwin, K. S., Hafner, S. D., \& Buff, M. F. (2003). Longterm trends in sodium and chloride in the Mohawk River, New York: the effect of fifty years of roadsalt application. Environmental Pollution, 124, 273281. doi:10.1016/S0269-7491(02)00481-5.

Goodrich, B. A., Koski, R. D., \& Jacobi, W. R. (2008). Roadside vegetation health condition and magnesium chloride $\left(\mathrm{MgCl}_{2}\right)$ dust suppressant use in two Colorado, U.S. counties. Arboriculture and Urban Forestry, 34, 252-259.

Goodrich, B. A., Koski, R. D., \& Jacobi, W. R. (2009). Condition of soils and vegetation along roads treated with magnesium chloride for dust suppression. Water, Air, and Soil Pollution, 198, 165-188. doi:10.1007/s11270-008-9835-4.

Green, S. M., Machin, R., \& Cresser, M. S. (2008). Effect of long-term changes in soil chemistry induced by road salt applications on $\mathrm{N}$ transformations in 
roadside soils. Environmental Pollution, 152, 20-31. doi:10.1016/j.envpol.2007.06.005.

Hellstén, P. P., Kivimäki, A.-L., Miettinen, I. T., Mäkinen, R. P., Salminen, J. M., \& Nystén, T. H. (2005). Degradation of potassium formate in the unsaturated zone of a sandy aquifer. Journal of Environmental Quality, 34, 1665-1671. doi:10.2134/jeq2004.0323.

Howard, K. W. F., \& Maier, H. (2007). Road deicing salt as a potential constraint on urban growth in the Greater Toronto Area, Canada. Journal of Contaminant Hydrology, 91, 146-170. doi:10.1016/j. jconhyd.2006.10.005.

Innes, J. L. (1993). Forest health: Its assessment and status. Wallingford: CAB International.

Judd, J. H. (1970). Lake stratification caused by runoff from street deicing. Water Research, 4, 521-532. doi:10.1016/0043-1354(70)90002-3.

Kabata-Pendias, A., \& Pendias, H. (2001). Trace Elements in Soils and Plants. Boca Raton: CRC.

Kayama, M., Quoreshi, A. M., Kitaoka, S., Kitahashi, Y., Sakamoto, Y., Maruyama, Y., et al. (2003). Effects of deicing salt on the vitality and health of two spruce species, Picea abies Karst., and Picea glehnii Masters planted along roadsides in northern Japan. Environmental Pollution, 124, 127-137. doi:10.1016/S0269-7491(02)00415-3.

Kincaid, D. W., \& Findlay, S. E. G. (2009). Sources of elevated chloride in local streams: groundwater and soils as a potential reservoirs. Water, Air, and Soil Pollution, 203, 335-342. doi:10.1007/s11270-0090016-x.

Lima, J. L. F. C., Rangel, A. O. S. S., Renata, M., \& Souto, S. (2000). Assay of plant tissues for elemental content by flow injection analysis. Communications in Soil Science and Plant Analysis, 31(7), 1071-1109. doi:10.1080/00103620009370498.

Lorenz, M. (1995). International co-operative programme on assessment and monitoring of air pollution effects on forests. ICP Forests. Water, Air, and Soil Pollution, 85, 1221-1226. doi:10.1007/BF00477148.

McBean, E., \& Al-Nassri, S. (1987). Migration pattern of de-icing salts from roads. Journal of Environmental Management, 25, 231-238.

Migaszewski, Z. M., Gałuszka, A., \& Pasławski, P. (2004). Baseline element concentrations in soils and plant bioindicators of selected national parks of Poland. $G e$ ological Quarterly, 48(4), 383-394.

Norrström, A. C. (2005). Metal mobility by de-icing salt from an infiltration trench for highway runoff. Applied Geochemistry, 20, 1907-1919. doi:10.1016/j. apgeochem.2005.06.002.

Norrström, A. C., \& Jacks, G. (1998). Concentration and fractionation of heavy metals in roadside soils receiving de-icing salts. The Science of the Total Environment, 218, 161-174. doi:10.1016/ S0048-9697(98)00203-4.

Novotny, V., Muehring, D., Zitomer, D. H., Smith, D. W., \& Facey, R. (1998). Cyanide and metal pollution by urban snowmelt: impact of deicing compounds. Water Science Technology, 38(10), 223-230.
Novotny, E. V., Murphy, D., \& Stefan, H. G. (2008). Increase of urban lake salinity by road deicing salt. Science of the Total Environment, 406, 131-144. doi:10.1016/j.scitotenv.2008.07.037.

Porcelli, C. A., Gutierrez Boem, F. H., \& Lavado, R. S. (1995). The $\mathrm{K} / \mathrm{Na}$ and $\mathrm{Ca} / \mathrm{Na}$ ratios and rape seed yield, under soil salinity or sodicity. Plant and Soil, 175, 251-255.

Ramakrishna, D. M., \& Viraraghavan, T. (2005). Environmental impact of chemical deicers-a review. Water, Air, and Soil Pollution, 166, 49-63. doi:10.1007/ s11270-005-8265-9.

Rasa, K., Peltovuori, T., \& Hartikainen, H. (2006). Effects of de-icing chemicals sodium chloride and potassium formate on cadmium solubility in a coarse mineral soil. Science of the Total Environment, 366, 819-825. doi:10.1016/j.scitotenv.2005.08.007.

Robidoux, P. Y., \& Delisle, C. E. (2001). Ecotoxicological evaluation of three deicers $(\mathrm{NaCl}, \mathrm{NaFo}$, CMA) effects for terrestrial organisms. Ecotoxicology and Environmental Safety, 48(2), 128-139. doi:10.1006/eesa.2000.2035.

Rosenberry, D. O., Bukaveckas, P. A., Buso, D. C., Likens, G. E., Shapiro, A. M. \& Winter, T. C. (1999). Movement of road salt to a small New Hampshire Lake. Water, Air, and Soil Pollution, 109, 179-206. doi:10.1023/A:1005041632056.

Sæbø, A., Benedikz, T., \& Randrup, T. B. (2003). Selection of trees for urban forestry in the Nordic countries. Urban Forestry \& Urban Greening, 2, 101-114. doi:10.1078/1618-8667-00027.

Tan, K. H. (2005). Soil sampling, preparation, and analysis, 2nd Edn. New York: Taylor \& Francis.

Thunqvist, E. -L. (2004). Regional increase of mean chloride concentration in water due to the application of deicing salt. Science of the Total Environment, 325, 29-37. doi:10.1016/j.scitotenv.2003.11.020.

Trahan, N. A., \& Peterson, C. M. (2007). Factors impacting the health of roadside vegetation. Colorado Department of Transportation Research Branch. Final Report No. CDOT-DTD-R-2005-12.

Trahan, N. A., \& Peterson, C. M. (2008). Impacts of magnesium chloride-based deicers on roadside vegetation. Transportation Research Circular, E-C126, 171-186.

US EPA. (1971). Environmental Impact of Highway Deicing. New Jersey: Edison Water Quality Laboratory. Edison.

US EPA. (1996). SW-846, Method 3050, Acid digestion of sediments, sludges, and soils, revised December 1996. Washington DC: US EPA.

Viskari, E. -L., \& Kärenlampi, L. (2000). Roadside Scots pine as an indicator of deicing salt use - a comparative study from two consecutive winters. Water, Air, and Soil Pollution, 122, 405-419. doi:10.1023/ A:1005235422943.

Zehetner, F., Rosenfellner, U., Mentler, A., \& Gerzabek, M. H. (2009). Distribution of road salt residues, heavy metals and polycyclic aromatic hydrocarbons across a highway-forest interface. Water, Air, and Soil Pollution, 198, 125-132. doi:10.1007/s11270-008-9831-8. 